\title{
William Notman's Portrait Photographs of the Wealthy English-speaking Girls of Montreal: Representations of Informal Female Education in Relation to John Ruskin's “Of Queens' Gardens" and Writings by and for Canadians from the
} 1850 s to 1890 s

\section{Loren Lerner}

\section{ABSTRACT}

This essay considers nine portrait photographs of the wealthy English-speaking girls of Montreal, taken in the photographic studio of William Notman (1857-1891). These photographs, now located in the Notman Photographic Collection at the McCord Museum of Canadian History, are also accessible through the museum's website. The analysis focuses on these images as a pictorial record of the informal education of girls according to the beliefs and convictions of the upper-middle-class. Central to this inquiry is John Ruskin (1819-1900), recognized for his vision of how girls should be educated. With Ruskin's "Of Queens' Gardens" (Sesame and Lilies, 1864) as a basis for discussion, this paper also explores the sentiments and opinions expressed in magazine articles, novels, books, and other texts about girls that were read in Canada between the 1850s and the 1890s. The objective in aligning particular visual representations with corresponding historical texts is to explore how the ideals of a girl's upbringing are embedded in Notman's portraits, and conversely how the images illuminate the texts.

\section{RÉSUMÉ}

Cet article examine neuf portraits photographiques de jeunes filles anglo-montréalaises de famille aisée, prises dans le studio photographique de William Notman (1857-1891). Ces photos, qui font partie des archives photographiques Notman du Musée McCord d'histoire canadienne, peuvent être consultées sur le site Internet du Musée. L'analyse se concentre sur ces images en tant que témoignage pictural de l'éducation informelle des femmes selon les croyances et les convictions de la classe moyenne supérieure. John Ruskin (1819-1900), reconnu comme visionnaire dans le domaine de l'éducation des filles, occupe un rôle central dans cette enquête. Son "Of Queens' Gardens " (Sesame and Lilies, 1864) sert de point de départ pour cet article qui traite également des opinions et des attitudes exprimées dans les magazines, les romans, les livres et autres textes sur les filles lus au Canada entre 1850 et 1890 . Comparant certaines représentations visuelles avec des textes historiques de la même période, l'auteur tente 
d'examiner comment l'éducation de la jeune fille idéale apparait à travers les portraits réalisés par Notman et, réciproquement, comment les images éclairent les textes.

\section{William Notman's Portrait Photographs ...}

William Notman was the photographer of choice for Montreal's wealthy Englishspeaking families from 1857, when he opened the Notman Photographic Studio in the heart of the city's business district, until his death in $1891 .^{1}$ The portraits, many of which were taken in his studio, ${ }^{2}$ chronicled the life-passage of girls from childhood to young adulthood. For interior views, Notman offered his customers several painted backdrops to choose from, as well as a variety of furnishings and props that he arranged to simulate the parlours, sitting rooms and libraries of Montreal homes. He excelled at positioning the girls in settings that reflected the season's fashions, either alone or in the company of their siblings or parents. The girls would stand next to a table or sit demurely on a chair or couch, often with a book in their hand or by their side, as if caught in the act of reading.

On occasion, Notman's girls were posed in a setting designed to look like the garden or patio of their home, or in a recreational environment such as a skating or curling rink or a hill for tobogganing. Despite the informality of these locations, the girls were always portrayed at their best, wearing good everyday clothing, a lovely dress or coat, or a splendid sporting outfit, with their hair coiffed to perfection. ${ }^{3}$ The unusual environment in these photographs was agreed upon in advance by the photographer and the girls' parents, who had decided it was suitable to the female character. When the photographs came home, they were often placed in the family's photographic album, a typical household object that would be proudly presented to relatives, friends, and suitors who were equally pleased to view it. ${ }^{4}$

In this essay, I explore nine of Notman's many portrait photographs of girls, now located in the Notman Photographic Collection at the McCord Museum of Canadian History in Montreal. ${ }^{5}$ These portraits portray the girls' loveliness, goodness and fine health, as Notman intended them to. ${ }^{6}$ After all, it was the Victorian Era, described by writers as "the age of children," when the public was fascinated with youth, especially the minds and bodies of young females. ${ }^{7}$ But Notman also thought of himself as an artist, and indeed he was a founding member of the Art Association of Montreal and frequently exhibited his photographs in the Association's annual exhibitions. As such, his pictures express a genuine artistic devotion to the female subject, one that was shared by many artists of his time, including painters Joshua Reynolds, Thomas Gainsborough, Sir Edward Burne-Jones, and Adolphe William Bouguereau; and photographers Lewis Carroll, Roger Fenton, and André Adolphe-Eugène Disdéri.

On the face of it, Notman's portrait photographs of Montreal girls are a celebration of girlhood, a testimony to the pride parents took in their daughters, a reflection of the public's fascination with youth and a manifestation of the photographer's fondness for his subject and his artistic ideas. In this study, I argue that there is another way to interpret these portraits, which is that they constitute a unique pictorial record of English upper-middle-class ideas on the raising of girls. In Montreal during this 
period, these ideas were expressed in a type of informal education that parents of this class believed was ideal for their daughters.

My analysis of these portraits as conveyors of educational values is based on three premises. The first states that a photograph is not exclusively a visual medium. It has an oral consciousness, which is to say that it is inherently affiliated with voices that articulate attitudes, values, sensibilities, identities, and self-worth. ${ }^{8}$ In fact, the oral aspect of society forms the basis of human relationships, and as such is always present to some degree. Inevitably, orality leaves its traces in visual images and written texts. This is also true of Notman's portraits of girls. For the purposes of this study, I investigated these portraits to discover how the voices embedded in contemporaneous texts communicate the beliefs of the people living during that time.

The second premise states that photographs that capture members of a specific community during a particular period are descriptive of a world view shared by those members. In this instance, the community is comprised of wealthy English Canadians living in Montreal, and the members being captured in photographs are the daughters of these families. The period is the Victorian Era, specifically, the $1860 \mathrm{~s}$ to the 1890s. Throughout these decades, Canadians of this newly-formed nation were engaged with each other critically and robustly in discussions about the education of youth.' Under particular scrutiny was the question of how to educate the "new" girls who were growing up in cities rather than on farms. ${ }^{10}$

The third premise states that when studying a world view as expressed in photographs, an interdisciplinary approach must be used. This means that the investigation must consider various written and visual sources of information in relation to one another. ${ }^{11}$ Canadian historians of the family and of education typically rely on a wide range of written sources, including public records, parliamentary debates, child-rearing manuals, advice literature, women's magazines, juvenile fiction, autobiographies, diaries, letters, and anecdotal writings. ${ }^{12}$ Using these sources, they examine the living environments of families, the upbringing of girls and the laws, policies, and practices governing child care and protection. When art historians and curators of museums and historic sites in Canada conduct investigations, for example, of children and families, they rely on pictures in various media and the material culture of clothing, household objects, manufactured goods, built forms, and physical spaces. ${ }^{13}$ This study differs from both of the above in that it uses a research strategy that begins by aligning a particular visual record with corresponding historical texts. By recognizing how the visual record - in this case Notman's portraits of girls - makes real the images suggested in the texts, it uncovers the oral underpinnings of the portraits. What is revealed in Notman's photographs, finally, is confirmation of the educational ideals described in the literature of that time.

Central to this inquiry is John Ruskin, the Victorian social commentator, art critic, and educator who was highly recognized for his vision of how girls should be educated. In the late 1850s and through the 1860s, Ruskin gave talks at Winnington Hall in Cheshire, England, a small school for girls headed by Margaret Bell, who believed in progressive educational practices. ${ }^{14}$ This experience, together with his growing affection for Rose La Touche, a ten-year-old Irish girl he met in 1858 and tutored 
in drawing and religion, precipitated his interest in a more liberal plan of education for girls. Of particular interest to my study is Ruskin's "Of Queens' Gardens," a lecture delivered in Rusholme Town Hall on December 14, 1864, and published some months later in the book Sesame and Lilies. ${ }^{15}$

Books by Ruskin were extensively read in Canada, and Ruskin himself was highly respected as someone "wholly, and emphatically, and uncompromisingly ethical and spiritual everywhere and always." 16 His new publications were announced in the Canadian press, and advertisements by Canadian booksellers consistently referred to him as an important author whose complete set of works were always available. His opinions on raising children, family life, ${ }^{17}$ and love and courtship ${ }^{18}$ were often quoted in Canadian newspapers and magazines. By 1886, Sesame and Lilies was considered a classic, with "Of Queens' Gardens” regarded as the best source on how to educate girls. In a brief biography of Ruskin that appeared on the front page of Northern Messenger, a weekly magazine devoted to religion and family reading, the writer emphasizes that Ruskin would have girls be "not only humane, tender and true, kind to strangers, refined, neat, and in a word, ladies, but trained in the habits of accurate thought..." 19 By this time, Sesame and Lilies was being listed in Northern Messenger as one of eighty books that could be purchased as a set for home and circulating libraries.

With Ruskin's “Of Queens' Gardens” as a guide, I demonstrate that many of the sentiments and opinions expressed in magazine articles, novels, books, and other texts about girls read in Canada between the 1850s and the 1890s can be found in the ideology espoused by Ruskin. This is not to suggest that the authors of these works were mimicking Ruskin's ideas. In reality, Ruskin's wise counsel was so well received by Canadian readers because most of what he said was in agreement with the progressive ideas that were slowly gaining ground in Canada during this era. Women especially became devoted followers of Ruskin in the latter part of his career precisely because they recognized their own thoughts in his writings. Further, though his recommendations were reformative to some degree, most of what he wrote steered a conservative course already emulated by Canadian families.

The observation made in this study is that Notman's photographs of young female subjects are part of a wave of cultural works produced during the Victorian Era that includes many different texts that are concerned with the best way to encourage growth and development in girls. By extrapolating from both Ruskin and a number of these texts, written by Canadians or available in Canada, I show how an investigation of published material reveals more explicitly the oral and visual messages present in Notman's portrait photographs of English girls from wealthy families in Montreal. ${ }^{20}$

We begin with a portrait of Florence Allan (1864) (fig. 1), who is about ten years old. Florence has been posed in a standing position, her full-length figure set in the centre of the composition. The scene, of a garden terrace, is enhanced by a painted backdrop 
that includes a trail of ivy cascading down a stone wall. Florence is wearing a play outfit - a long-sleeved bodice with button-down collar tucked into a high-waisted skirt. Her short hair, typical of children in the 1860s, is greased back and neatly parted. In her left hand, which leans comfortably against the edge of a rustic flowerpot, she holds a skipping rope. Florence appears content and secure in the cloistered space of the garden, her charm and natural beauty abundantly evident. Her refined countenance, modest attire, and graceful posture communicate that she is on her way to becoming a reserved and cultivated young woman.

In "Of Queens' Gardens," Ruskin begins by describing the kind of education that is appropriate for a girl: "Thus, then you have first to mould her physical frame." 21 He continues: "But you cannot hammer a girl into anything. She grows as a flower does." ${ }^{22}$ Here, Ruskin expresses his idea that women grow organically, which explains

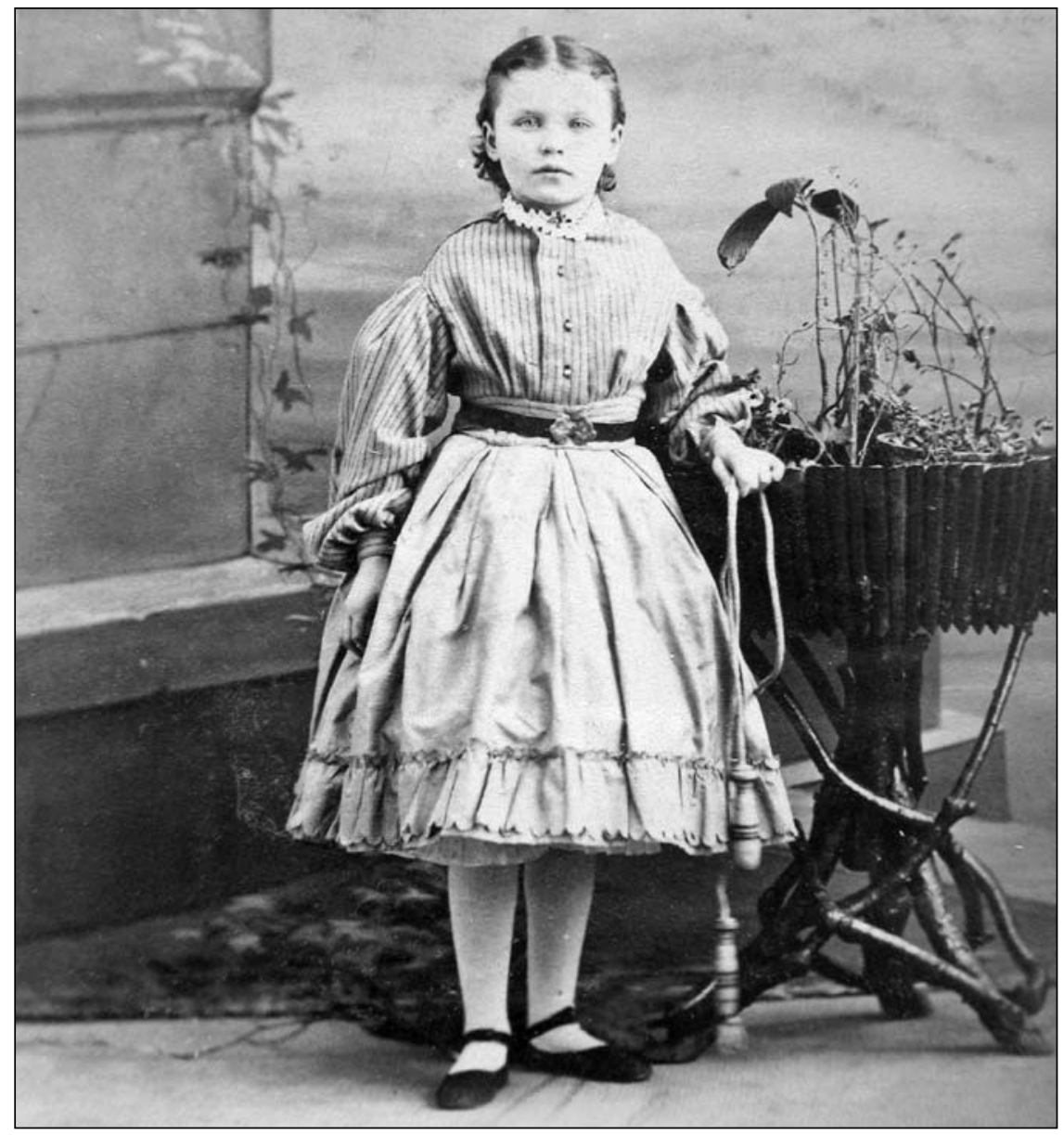

Figure 1: Miss Florence Allan, Montreal, QC, 1864. William Notman. I-10190.1. Courtesy of McCord Museum. 
the title of his lecture. He believed that the environment for "such physical training and exercise as may confirm her health, and perfect her beauty" was the garden at home. Quoting Wordsworth's poem “Three Years She Grew in Sun and Shower," he emphasizes that to make a girl lovely you must first make her happy, and that only through physical freedom and a corresponding freedom of the heart will she experience "vital feelings of delight." 23

When we observe Florence posing in Notman's garden setting, she appears to be already aware that her education will affirm her dignity and prepare her for the womanly duties of "true queenly power." If Ruskin had known Florence, he would have agreed that the place for her to grow most naturally was in her own backyard, protected from the dangers and ugliness of the outside world. In his photograph, Notman captures this belief: the "instincts of affection" are written on Florence's face, while the brightness of her eyes conveys "the eyes of innocence" and her "brow of virtue," ${ }^{24}$ both of which convey her charm.

Ruskin's notions reflect a perception among Canadians over several decades that a natural affinity existed between girls and gardens. In an article on gardening, published in Canadian Son of Temperance and Literary Gem ${ }^{25}$ in 1851, fourteen years before Ruskin produced "Of Queens' Gardens," the author recommends that every family have a flower garden that the daughters of the house can cultivate, observe, and admire, believing that "there is a strong sympathy between beautiful flowers and the minds, hearts and feelings of young ladies." Girls who occupied themselves with "cultivating a beautiful bed of flowers or some pet flower in a pot" were compared to lovely spring blossoms. With their "joyful faces" and "rosy cheeks," they were seen to be healthy and happy. Furthermore, it was understood that in tending their gardens, the girls were in fact preparing themselves to be wives and mothers, adept at caring for their homes and ready to devote the same loving attention they gave to their flowers to their families.

In Notman's portrait, Florence's face and clothing illustrate what people most wanted to see in a girl, according to Maud Cooke, author of Social Etiquette, or, Manners and Customs of Polite Society: Containing Rules of Etiquette for All Occasions (1896). ${ }^{26}$ Suitably dressed in a simply-cut outfit with little trimming, her attire imparts the "speech of her body." But by Cooke's account, we are not to focus on Florence's outfit but on the girl who is its soul. It is only in the subject's face, particularly in her eyes, that we will find traces of her character, no matter the communicative potential of the costume and other elements of the portrait. When we study Florence, we find in her penetrating gaze sincerity and strength of purpose. Although decorum dictated that a proper girl never display a pronounced facial expression or take up a dynamic pose, Florence genuinely appears to be a tender, loving and contented young girl.

Ruskin believed that girls engaging in outdoor pursuits should do so mostly in their gardens, where "the splendour of activity" would be appropriate for their "delicate strength.” ${ }^{27}$ In Notman's photographs, the most common reference to physical activity is the skipping rope, which is there in the portrait of Florence. Skipping was considered particularly advantageous for girls because it was not a rigorous form of exercise. "Skipping is exceedingly good exercise for a girl, every part of the body being 
put into action by it," was the advice given to mothers in $1880 .{ }^{28}$

Eventually, Notman perfected another arrangement that to his mind reflected even more accurately the healthy and vigorous disposition of Montreal girls: showcasing their distinctive vitality in a winter landscape. In an article in Canadian Magazine (1896), ${ }^{29}$ Reginald Gourlay praises the unique beauty and strength possessed by "the Canadian Girl" who has grown up in this country's cold climate. He was convinced, as many were, that the Canadian girl of this epoch promised to develop into one of the highest types of womanhood. ${ }^{30}$ She was "a beauty that will stand in the open air and a strong light; that strikes you at first, and grows on you afterwards. She is the flower of this strong, beautiful, northern land, and a full share of its vigour and the best of its beauty is concentrated in her." ${ }^{31}$

Notman managed to capture these qualities in Missie Maud Ogilvie (1867) (fig. 2), a portrait that shows a very sweet, very young child who is richly attired in a coat of napped wool or velvet and has a matching hat, collar and muff. Her high-end winter

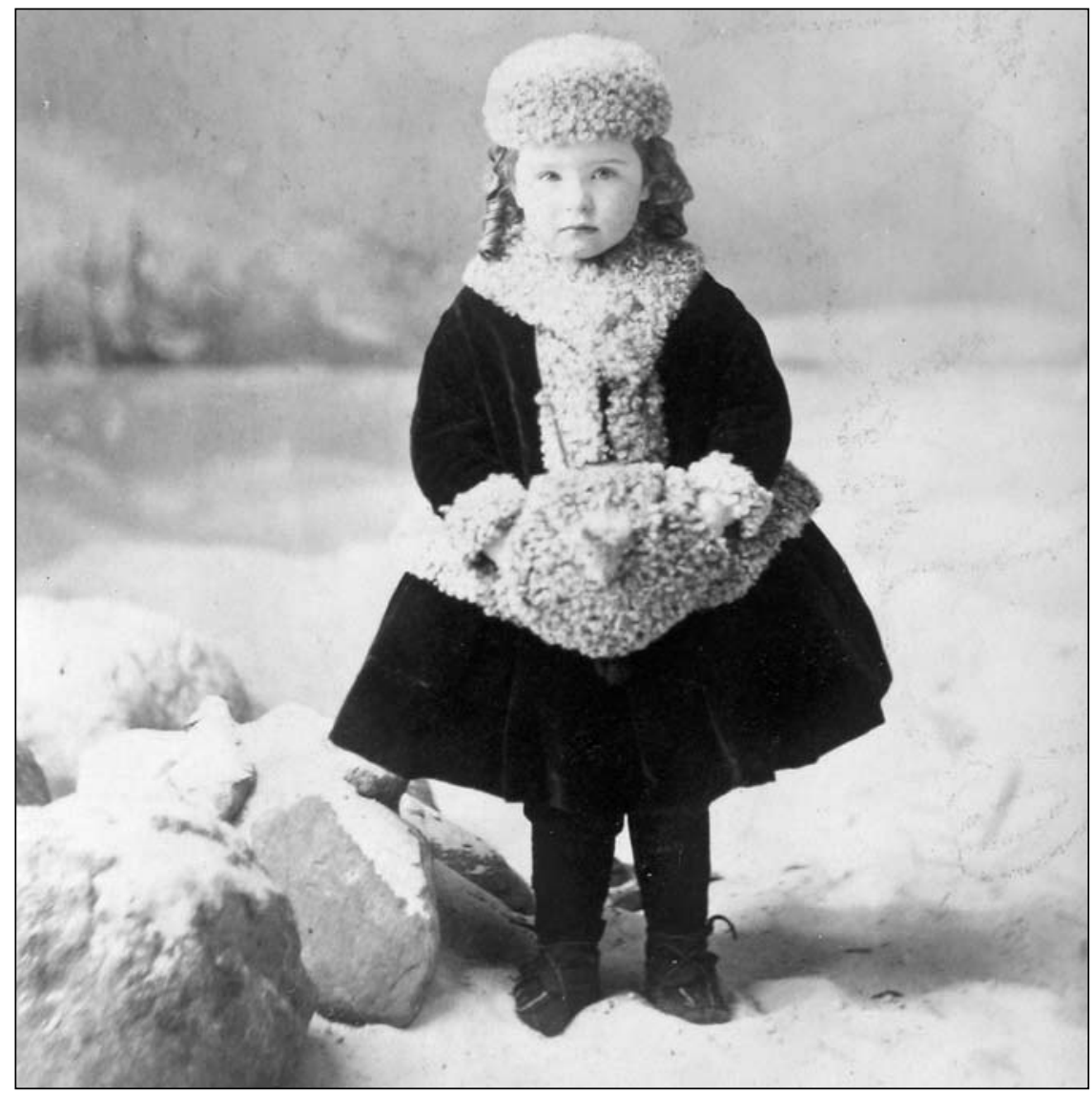

Figure 2: Missie Maud Ogilvie, Montreal, QC, March 1867. William Notman. I-25190.1. Courtesy of McCord Museum. 
wear reveals her status as a child of wealth. She stands, quite at ease, in a simulated winter landscape: the painted backdrop is stark and snowy, there are real boulders by her side, and the ground is covered with white fur and cotton wool to imitate snow. It is a construction that emphasizes the rustic outdoor life of robust Canadians. According to the popular sentiment of the time, Canadian girls were a hardy lot, tobogganing, snowshoeing or skating for hours on end in the winter landscape. These activities formed them into young women who were not only healthy and attractive, but independent and self-possessed.

Despite his assortment of outdoor scenes, Notman's most common photograph of the Montreal girl shows her standing or sitting alone or grouped with siblings and parents, a book in her hands or on a nearby table. In these images, the subject is formally posed and her bearing communicates that she is cultivated, attentive, and informed. The book appears to act as a marker that conveys the girl's wealthy status, suggesting as it does that she has leisure time in which to read. It also confirms that she is capable of absorbing factual information and reflecting on moral or practical counsel, and that she is appreciative of the literary world. ${ }^{32}$ An example of this can be found in Notman's portrait of Jane and Bessy Allan from 1861 (fig. 3), in which the sisters' bearing and fine clothes testify to the wealth Andrew Allan acquired in the shipping industry, while the turning of a page in the book communicates the girls' acculturation.

Whereas Ruskin's advice about a girl's physical development was conventional, the major thrust of his recommendations, that her education depended on the freedom to read, was considered progressive. The main theme in "Of Queens' Gardens" is the positive influence of reading on a girl's edification. Ruskin states: "You have first to mould her physical frame, and then, as the strength she gains will permit you, to fill and temper her mind with all knowledge and thoughts which tend to confirm its natural instincts of justice, and refine its natural tact of love." 33 To accomplish this formation, the girl must "use books rightly," which means reading the wisest and greatest authors for knowledge, thought, counsel, and the right opinion on matters of difficulty. The Allan girls are a vision of Ruskin's precepts in that they hold a "wellchosen reading" that will instill in them "well-directed moral training." ${ }^{34}$ They have a "queenly status" because the time devoted to reading will give them the "possession of a power over the ill-guided and illiterate." 35

In discussing the kind of book a girl ought to read, Ruskin insists that she take up the same books a boy would and learn the same serious subjects, but "differently directed." ${ }^{36}$ A man's learning should be foundational and thorough, while a woman's should be general, accomplished and helpful. A girl's learning must develop in her the qualities of patience, thoughtfulness, and quick wittedness, so that she is "afterwards fittest for social service." ${ }^{37}$ As for the choice of books, the scope is broad, including history, philosophy, political essays, and good novels, so that "whether novels, or poetry, or history be read, they should be chosen, not for their freedom from evil, but for their possession of good." 38

In concert with Ruskin's ideas and the surrounding discourse, it was common for Canadian books, magazines, and newspapers to dispense advice on what a child, 


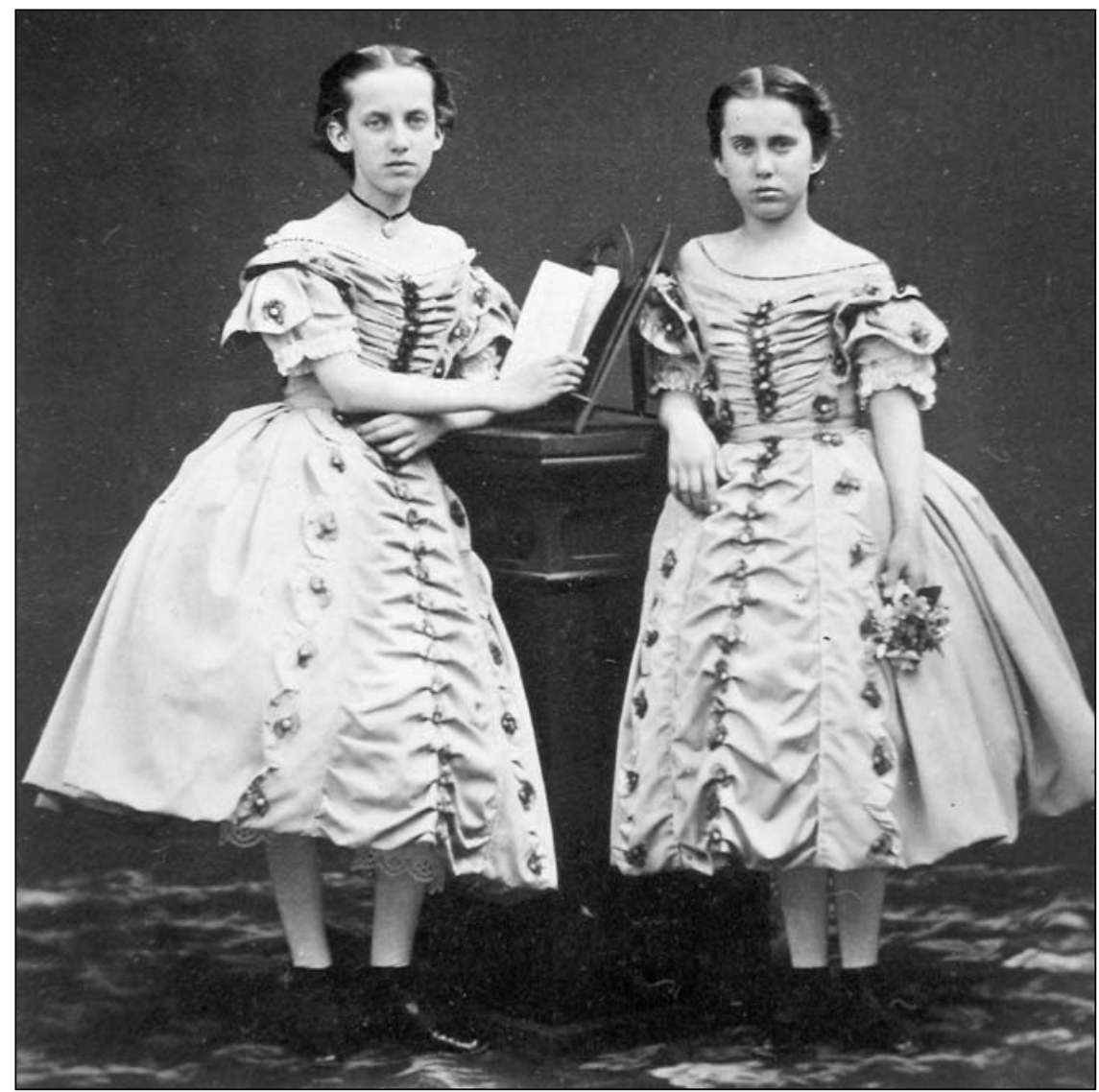

Figure 3: Mr. A. Allan's two girls, Montreal, QC, 1861. William Notman. I-80.1. Courtesy of McCord Museum.

particularly a girl, should read to better herself. One example comes from author and journalist Madge Merton, who wrote in 1896: "Girls ought to read all kinds of books, including those that teach something or inspire the reader to learn something ... books that honour old age and venerate childhood, that unlock the mysteries of nature, and point to the Divine through them all." $\mathrm{a}^{39}$ She continued: "What is right for a woman is right for a man and girl should read the same books her brother should read."

As increasing numbers of women in Canada became serious readers, female authors, many of them Canadian, obliged this burgeoning audience by writing novels for mothers and daughters that emphasized how a girl's intellectual growth and general maturity could be stimulated by reading. ${ }^{40}$ The plots of these novels understandably centred on the home and family life, emotions, friendship, courting, and other typical female preoccupations. Many included themes related to intellectual pursuits. For Ruskin, reading taught women about their domestic responsibilities because it 
helped prepare them for their "household, and queenliness." ${ }^{41}$ The home, according to Ruskin, was the true place of a woman's power, where only love and peace could enter. It was "a sacred place," "a temple of the hearth," and a shelter from the injury, hostility, error, and evil of the outside world. ${ }^{42}$

In Canadian Illustrated News, a magazine produced in Montreal in the 1870s, the editors displayed a fondness for the subject of how to educate girls. They also played a role in training girls to run households by publishing articles like "What to Teach Our Daughters," 43 "The Best Education," 44 and "What to Do with the Girls." ${ }^{45}$ The author who wrote "Hearth and Home - Female Education" was open in expressing her belief that reading provided girls with "real and proper weight in society" when used with "proper discretion," and would not make them unfit for the "everyday business of life" and "homely objects." 46

The photograph of Jane and Bessy Allan already noted above (figure 3) could be an illustration of the ideas discussed in "Hearth and Home - Female Education." The sisters are standing at home elegantly posed in exquisite dresses, the book on display indicative of the learning essential for their successful entry into society. Although the girls are no more than twelve years old and are still wearing short dresses, they are fashionably attired as if on their way to a ball, not as participants but as children in attendance with their parents. Standing close to each another, they represent the idealized life of the upper-middle-class female child. The sisters are united not only in the act of reading but by virtue of communal tastes and values.

Notman consistently succeeded in conveying his young subjects as thinkers who possessed a developing mind. For his part, Ruskin believed that a girl's mind grew stronger through the act of reading, advancing both her thinking skills and her ability to feel: "It is not the object of education to turn a woman into a dictionary, but it is deeply necessary that she should be taught to enter with her whole personality into the history she reads; to picture the passages of it vitally in her own bright imagination; to apprehend, with her fine instincts, the pathetic circumstances and dramatic relations." ${ }^{47}$ The object of educating girls was to teach them to engage with a book in the hope that their minds would begin to sympathize with, understand, and develop thoughts of love and piety.

This blend of thinking and feeling appears on the face of the young woman in Miss May Frothingham (1867) (fig. 4). With her hair neatly tied up and wearing a long day dress that reflects the style of the times, May is leaning over a large book that has been placed on a small table. Her eyes are raised as if she is meditating on what she has just read. With her contemplative look, May makes visual Ruskin's ideas about the thinking girl. As well, she reflects the merits described by Canadian writers who had clear-cut ideas about the right way for girls to read. In her article on children's reading in Canadian Magazine (1896), for example, Madge Merton underscores the conviction that "assimilation of thought and inspiration for thinking are the true objects of serious reading." 48

Seen from this viewpoint, there is no doubt that May is seriously contemplating her reading, having understood the educational benefits that come from this activity. Although her standing position is obviously unnatural given the context, it is 


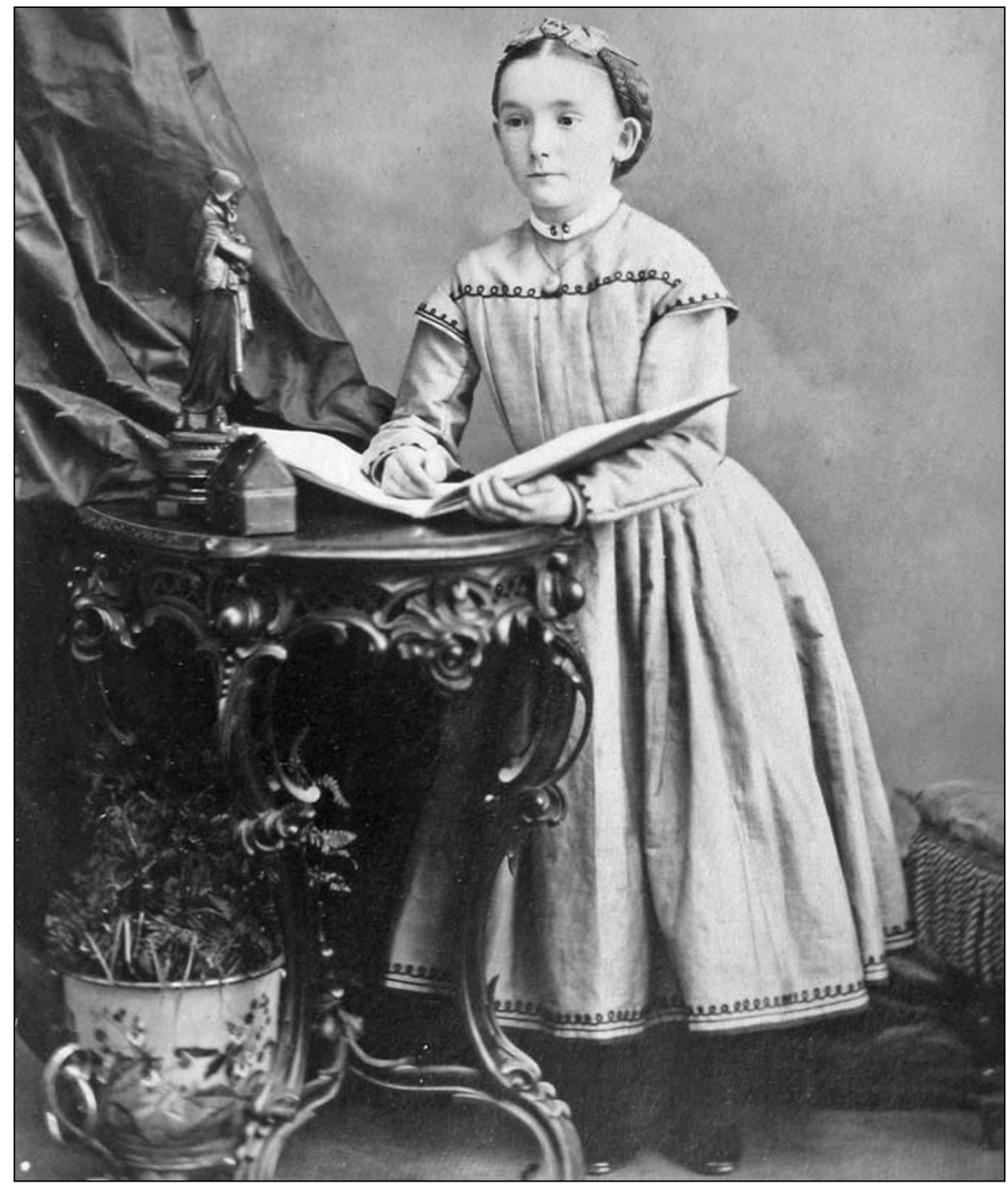

Figure 4: Miss May Frothingham, Montreal, QC, 1867. William Notman. I-26445.1. Courtesy of McCord Museum.

important for another reason. May's full figure confirms that her body is growing along with her mind, curvaceous like the flowing drapery behind her and cultivated like the potted plant by her feet. The statue of Shakespeare that sits on the table is a meaningful symbol, implying as it does that May is being educated by reading Shakespeare and other fine literature at home.

The reading material often seen in Notman's photographs of girls is the illustrated book or magazine. In the photograph Misses M. \& E. Allan (1871) (fig. 5), one of the girls has looked up from a picture book she was reading while waiting with her sister to go on a family outing. The other is gazing lovingly at what appears to be the 


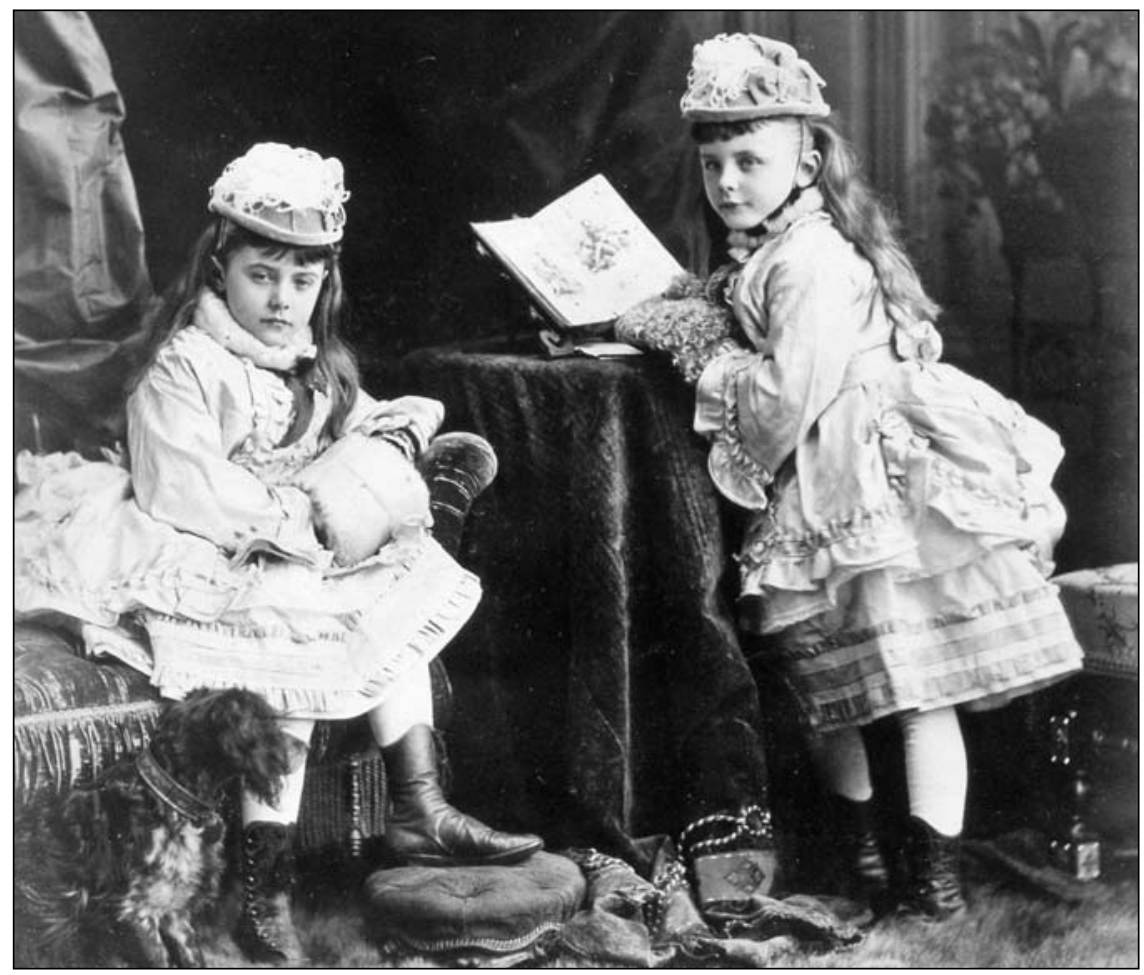

Figure 5: Misses M. \& E. Allan, Montreal, QC, 1871. William Notman. I-68654.1. Courtesy of McCord Museum.

family pet but is actually a stuffed dog from Notman's collection of accessories. In this charming domestic scene, the girls are fashionably dressed in matching outfits and bonnets, the status symbols of a wealthy Montreal family.

The prevalence of illustrated books and journals in Notman's portrait photographs can be explained in part by Notman's own interest in art and illustration. ${ }^{49}$ But his obsession with pictures was also symptomatic of the pedagogical convictions of the time. By the 1860s, with the invention of better paper and type, the public had come to realize the educational value of the printed image. ${ }^{50}$ As the art of illustration flourished in children's books, adult books, and journals, Victorian culture became ever more receptive to the close relationship between reading a book and looking at a work of art. The trend of publishing profusely illustrated works had begun.

It seems evident that one of the consequences of the proliferation of illustrated books and magazines was that girls would be among the new readership. But Ruskin provides a more profound explanation as to why illustration was considered important for the healthy growth of children. For him, seeing was a fundamental way to develop the capacity to imagine and think and ultimately to acquire knowledge of the world. ${ }^{51}$ In "Of Queens' Gardens" he writes: "Then, in art, keep the finest models before her, and let her practice in all accomplishments be accurate and thorough, so 
as to enable her to understand more than she accomplishes. I say the finest models - that is to say, the truest, simplest, usefullest." 52

In effect, Ruskin believed that girls should learn to draw. This was an intellectual activity that required the practitioner to learn how to read the visual image. For him, seeing was intrinsically linked to reading, whether "reading" meant viewing nature, contemplating Joseph Turner's landscape paintings or William Holman Hunt's print illustrations, or reading books by Plato, Shakespeare, Thomas Carlyle, or Francis Bacon. ${ }^{53}$ One of the greatest values of learning, said Ruskin, was acquiring the ability to discern the relationship between perception and interpretation and between intellectual and moral activity, whether looking at a real work of art or its reproduction in a book. That close association is described explicitly in the photograph of Miss Frothingham (1882) (fig. 6), whom we find sitting in a chair in a position one would normally assume for reading. In this instance, however, the subject is viewing, or "reading," a painting that is propped up on a table next to her.

In the late 1870 s, although he continued to portray older girls reading at home or in a garden setting, dressed in an everyday outfit or for a special occasion, Notman added a new type of photograph to his repertoire. This was the young woman who

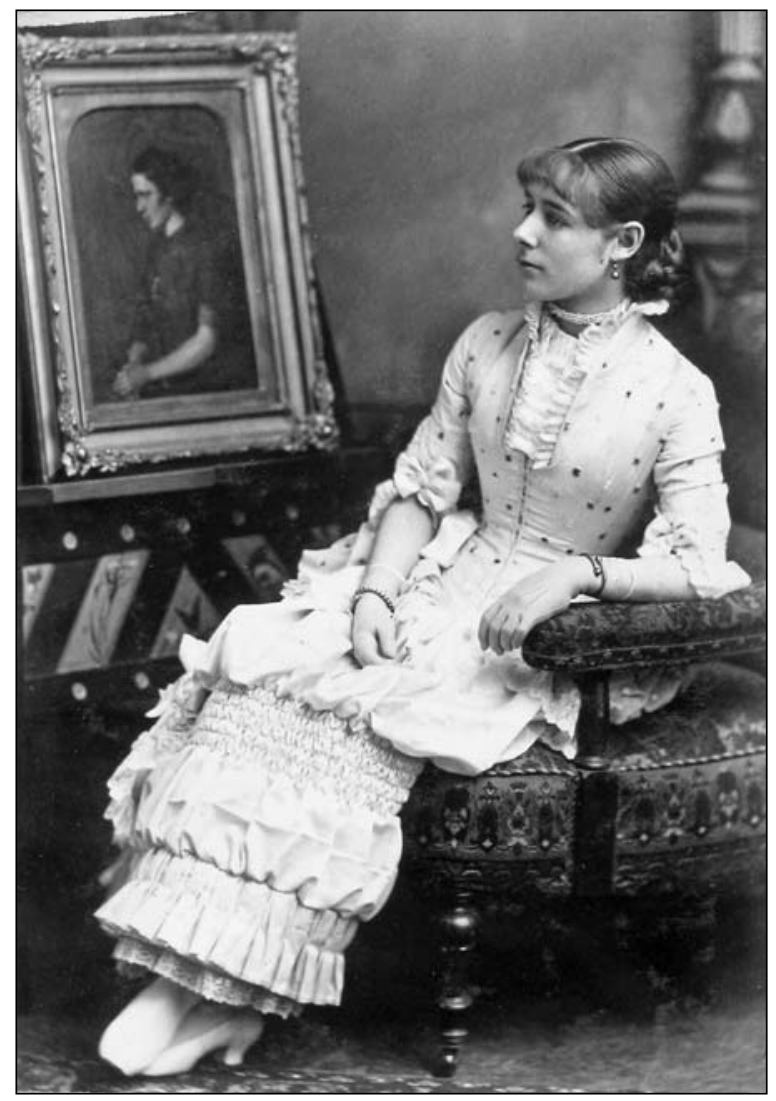

Figure 6:

Miss Frothingham, Montreal, QC, July 10, 1882. Notman \& Sandham. II-65839.1.

Courtesy of McCord Museum. 
demonstrated her talents and accomplishments in art and music. In a photograph of this type, Miss Ross is sitting before a small table (1876) (fig. 7), her hands poised as if she is playing the piano. The photograph was later inserted into a composite of the Ross family, to which was added a painting of the setting and piano (fig. 8). In this family portrait, the subject entertains her parents and siblings in a living room full of books and decorated with sculptures displayed under glass on the mantelpiece. Ruskin considered art and music to be essential to the proper acculturation of girls, with their "practice" in these accomplishments, as he emphasizes in "Of Queens' Gardens," to be "accurate and thorough so as to enable her to understand more than she accomplishes." 54

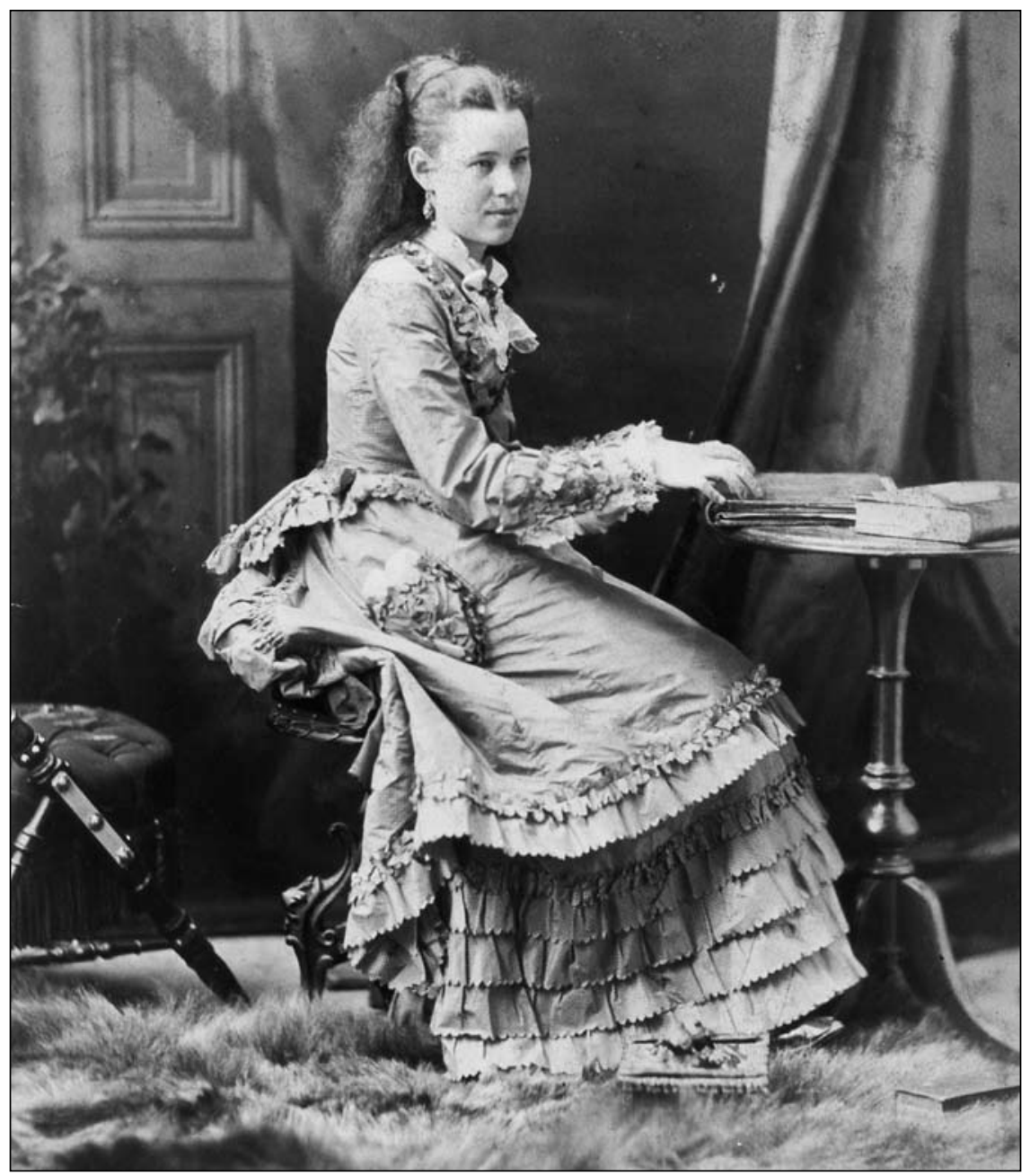

Figure 7: Miss Ross, posed for a composite, Montreal, QC, 1876. William Notman. II-40916.1. Courtesy of McCord Museum. 


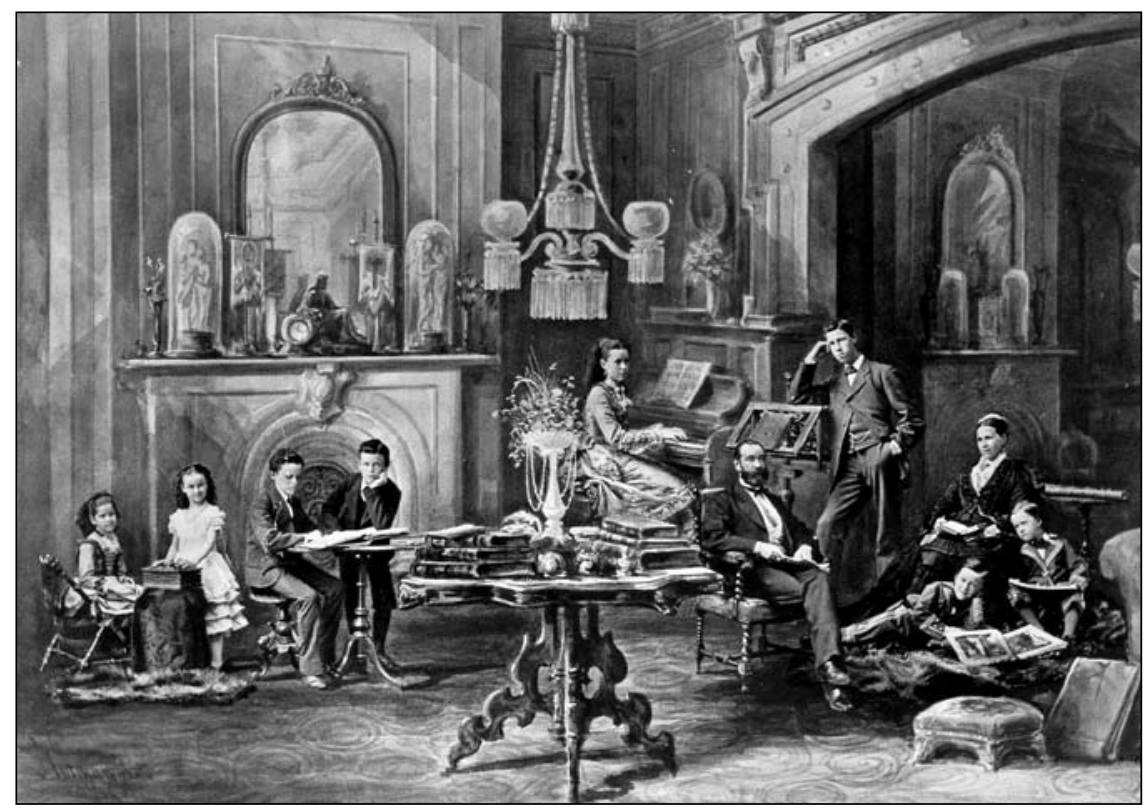

Figure 8: Philip S. Ross and family, Montreal, QC, composite, 1876. Notman \& Sandham. II-41409.1. Courtesy of the McCord Museum.

As exemplary as these pursuits were, they involved certain pressures that Hops Ledyard illuminates in a short story published in Northern Messenger in $1887 .{ }^{55}$ Here, Kate "like many other girls found her time more and more occupied as she neared seventeen. She took music lessons, and was expected to practice for at least an hour a day. Then 'all the girls' took drawing, and she began. From early to late she studied, recited or practiced. She heard of books which she longed to read but there was no time" Finally, on her seventeenth birthday, Kate decides, with her mother's consent, to give up some of her lessons for a year so she can help with the housework. "Kate immediately shut the piano, laid aside her drawing book and retired from the geometry, rhetoric and philosophy classes, so getting time to study her lessons during school hours. The time before given to the piano was devoted to careful reading, under her brother's guidance; the hours formerly spent over the additional studies and drawing were devoted to housework." Although Kate renounces music and art (while continuing to give herself "to wholesome solid reading"), she reminds her mother that "a married cousin had no time for music," showing that she recognizes that her priorities are to make herself ready for the responsibilities of marriage and family life.

Notman's photographs ignore these pressures and document what appears to be the smooth transformation of Montreal girls into young women who are busy preparing to be wives and mothers. Miss J. Allan (1866) (fig. 9), attired in a fine dress suitable for visiting or receiving guests at home, poses gracefully in a profile view, standing decorously next to a book and a vase of flowers. This picture of the mature 


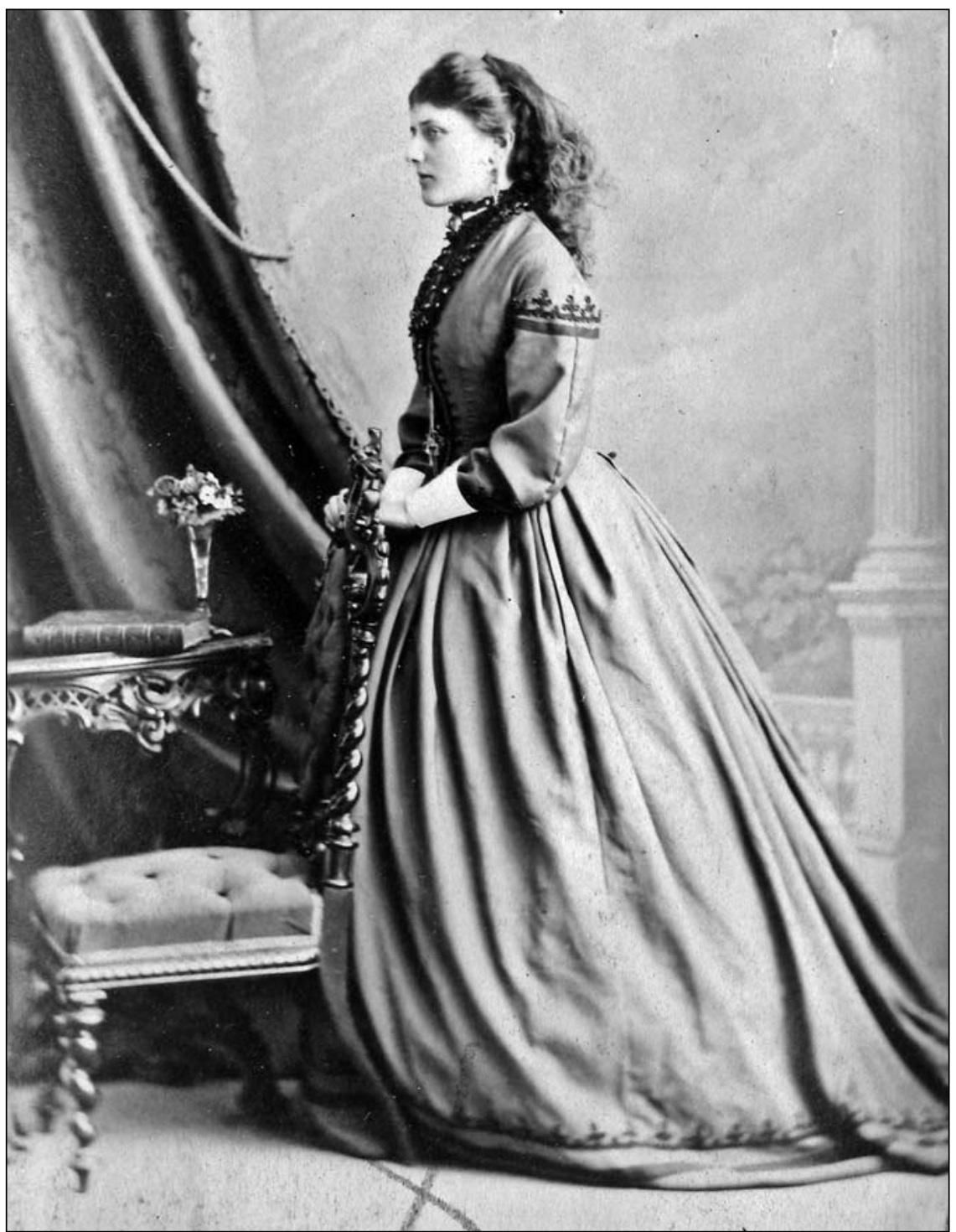

Figure 9: Miss J. Allan, Montreal, QC, 1866. William Notman. I-19813.1. Courtesy of the McCord Museum.

daughter serves as a visual announcement of her readiness for marriage. The intended audience could be the suitor himself or a relative or friend acquainted with a marriage prospect.

Despite Ruskin's progressive ideas about educating girls — insisting that a girl not be a "man's slave" or "shadow" but his "helpmate" ${ }^{\text {— }}$ in the final analysis her education is "differently directed," which is to say that its first purpose is to train her to 
become the perfect wife. ${ }^{57}$ Although in "Of Queens' Gardens" he proposes that the Winnington school for girls make significant improvements in their program, he unequivocally declares that "a woman ought to know the same language, or science, only so far as may enable her to sympathize in her husband's pleasures, and in those of his best friends." 58

Late nineteenth-century guidebooks on courtship and marriage mirrored Ruskin's attitude, as did Notman's photographs of mature girls. It is expected of Miss Allan that, as described by Annie Swan in Courtship and Marriage and the Gentle Art of Home-Making (1893), her "own innate delicacy and niceness of perception will guide her now to act, and if the attentions be acceptable to her she will give just the right need of encouragement, so that the course of true love may run smoothly towards consummation." ${ }^{59}$ According to the author of The Ladies Book of Useful Information Compiled from Many Sources (1896), "During your courtship let me entreat you to be very careful and circumspect," and, "God has made you a woman; and believe me, as there is no fairer, so there is no nobler creature than woman. She is formed to be her husband's helpmate and the mother of his children, and the all-important work of training these for heaven depends mainly upon her." ${ }^{60}$

Ruskin's recommendations in "Of Queens' Gardens" fall along class lines. Despite his belief in universal education, he acknowledges that learning is connected to aptitude and circumstance. In a letter dated August 8, 1871, written by Ruskin to formally inaugurate the St. George's Fund, whose purpose was to establish a guild where working-class families could cooperatively produce their own food and goods and earn a living, he offers a synopsis on the education of poor children. Girls should learn "to spin, weave, and sew, and at a proper age to cook all ordinary food exquisitely; the youth of both sexes to be disciplined daily in the strictest practice of vocal music; and for morality, to be taught gentleness to all brute creatures - finished courtesy to each other - to speak truth with rigid care, and to obey orders with the precision of slaves. Then, as they get older, they are to learn the natural history of the place they live in - to know Latin boys and girls both - and the history of five cities: Athens, Rome, Venice, Florence, and London." ${ }^{61}$ Although Ruskin believed that working-class girls should learn music, history, and Latin, he fell short of imaging an education for them that equalled the opportunities offered to girls from the moneyed classes.

Most of the girls who came to Notman's studio to have their pictures taken were city girls from upper-middle-class families, and as such they were attractive marriage prospects. However, they were very different from the majority of Canadians of a similar age who worked long hours on the farm or in a shop or factory to make a living. It was not uncommon for rich girls to be criticized for their easy life and superficial preoccupations. In 1880, a writer for Canada Presbyterian states that the "hard-worked, tired-out shop-girls, who have so few hours for repose, are often happier, because more genuinely self-respecting, than are some indolent, dawdling young ladies, who kill time by reading silly novels and whose chief aim seems to be the preservation from soil of their soft, useless hands." ${ }^{62}$ Reginald Gourlay argues in his article on the Canadian girl from 1896 that a young woman living in the "backwoods" possesses a better, more 
genuine education than city girls. She has "a frank kindliness of manner, an innocent self respect, and the remarkable equipoise and common sense which is to be found in her as well as in her more cultured sister. Add to this an intense desire for self improvement, and for such culture as she can grasp.... The girls in frontier places read more than all the rest of the family put together, and often amazingly good books." ${ }^{3}$

Many people were critical of the education wealthy girls received, believing it was irrelevant to real life and left the girls unprepared to deal with harsh realities such as the death of a loved one or a financial crisis in the family. According to an article in The Canadian Independent (1885), written by the well-known author Louisa May Alcott, a girl needs "a profession or trade to fall back upon in time of need, that she may not be dependent or too proud to work for her bread." ${ }^{64}$ As the following excerpts from novels reveal, not everyone was enthralled with the results of the acculturation Ruskin envisioned. Casper Brooke in Brooke's Daughter reproaches himself for "having allowed his foolish frivolous wife to bring up his daughter in a place where she had been taught nothing but embroidery and dancing." ${ }^{65}$ Frances Willard in Glimpses of Fifty Years: Tthe Autobiography of an American Woman (1889) expresses her dismay with her father, who wanted her to sing for him and whose idea "was that girls and women were to find their sphere in the home, and not elsewhere, and that the more accomplished they could be the better. I did not take kindly to this..." 66

From the 1850 s to the 1890 s, opinions about the right way to educate young women were in a state of flux. In an article titled "Higher Education for Women" in Canadian Illustrated News (1873), the author quotes Colonel Higginson, who says, "The question of intellectual education is not one thing for man and another for women, any more than the question of healthful diet is one thing for a man and another for a woman.... Whatever is best for the mind is best for the female mind. All the questions of modes of instruction, kindergartens and object lessons, science and literature, Greek and German, required and elective studies - all these must be essentially the same for woman as for man. All the problems of education seem to present themselves the same way at Harvard for boys, at Vassar for girls, at Michigan and at Cornell for the two united." 67

Ten years later in the same magazine, in an article also titled "Higher Education for Women," the author emphasizes: "We clearly recognize two distinct types of womanhood, between which all degrees of each are to be found. On the one hand, the timid, confiding, trusting woman, who, after completing her school or convent education, so comes to realize that her mission in this world is a domestic one with all the mingled trials and pleasures which this word implies. On the other hand, we see the self-confident, self-asserting, self-reliant, fearless, masculine woman, who feels irresistibly impelled to push forward into the realms of science and for whom the domestic duties have been but a second attraction. These two types are both admirable; the one lovable, the other grand and noble." 68

An example of the "grand and noble" type can be found in a photograph taken by Notman of Miss S.F. Allan, a student at Vassar College in Poughkeepsie, New York (1870) (fig. 10). With more and more girls leaving home to study, Notman had seized upon the opportunity to set up studios at several American colleges, and one of 
the settings he provided his customers was a college residence. Wearing a fashionable dress, Miss Allan is posed in one of those settings next to a table that holds a pile of books. A folio of print illustrations sits on another table to her right. In her hands she has a letter, from a suitor, perhaps, indicating that higher learning and courtship are compatible. Or maybe the correspondence is from home, in which case it represents the continuing bond between the young woman and her family. But the books on the table are not related to reading at home, rather, they hold information that will further her college education. While it would be many years before women brought home university degrees, with the creation of colleges like Vassar, which had the dual role of being a finishing school and a place of higher learning, the tide was beginning to turn.

With the help of Ruskin's "Of Queens' Gardens" and other literature of the time, we can learn more about the context and character of Notman's images of wealthy

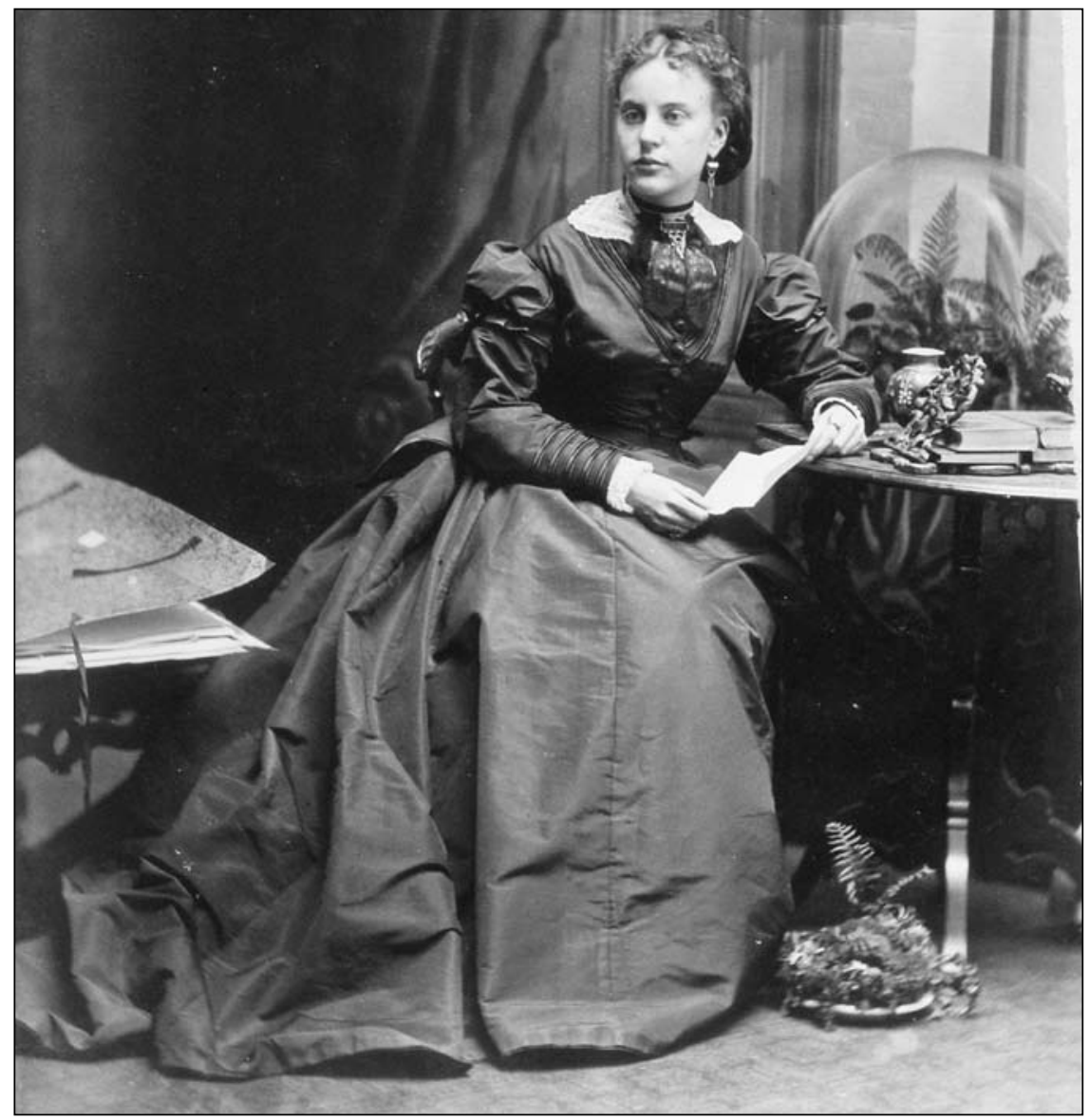

Figure 10: Miss S. F. Allan, student, Vassar College, Poughkeepsie, NY, 1870. William Notman. I-47066.1. Courtesy of the McCord Museum. 
English Montreal girls and improve our understanding of what was expected of these girls and how education and upbringing were tailored to help them meet those expectations. In Notman's visual record, we see that society had hopes for its daughters that went beyond growing into women who were exclusively devoted to husband and home. At first slowly and then more vigorously, young women were encouraged to be reading, thinking people. Although Ruskin's views on educating girls were progressive only in small part, the significance of this part - that girls should read what boys were reading - had consequences that reverberated in the minds of both ordinary people and thinkers who had begun to want more for girls than a life of domesticity. Ruskin's theories not only dovetailed with this nascent thinking, but with the notion, increasingly explored in books and magazines, that young women would do well to take up a profession. With the establishment of the first colleges for girls, women experienced a new independence of body and mind and further encouragement to think and act responsibly. However, the belief persisted for some time that these advances for women should enhance, not replace, their desire to strive for love and peace at home and in the world.

Working from sources taken from a particular period, this study brings into focus the attention that was devoted, in pictures and in text, to an idealized image of the girl. We also glimpse the gaps between this perceived ideal and the lived reality based on class, background, location, and economic status. Missing from this preliminary investigation is archival evidence that pertains to the historical experiences of these wealthy Montreal girls. My hope is that as I pursue my research through diaries, letters, and autobiographies - sources that have assisted Cynthia Comacchio ${ }^{69}$ and Neil Sutherland ${ }^{70}$ in their pivotal studies on the history of education in Canada - I will discover more about the contradictions and fictions that shaped these visual representations. Further, by studying the private records of the mothers of these daughters and the women who were once these children, I expect to learn more about how the upbringing of these girls was closely identified with adult selfhood.

In my view, this essay is a self-contained study with its own unique merits. It shows how the portrait photograph is a powerful means for shaping personal and cultural memory. The analysis demonstrates the inter-textuality of text and image by discovering connections between oral and visual representations that deal with the same aspect of a girl's life, such as reading or playing a musical instrument. Striking similarities are also revealed between texts and images that address discussions about girls and ideas relating to the ideal girl. In addition, we have seen that through the process of accrual - by virtue of repetitions, borrowings, and extensions from one image or text to another - particular ideas about educating young females came into being. Finally, Notman's portrait photographs echo the thought and speech of the English upper-middle-class people who lived in Montreal during the Victorian Era, making visible their efforts to communicate to each other a distinct ideology about how to raise their daughters. 


\section{Notes}

1 Stanley G. Triggs, The Composite Photographs of William Notman (Montreal: McCord Museum of Canadian History, 1994); S. Triggs, Le Studio de William Notman: Objectif Canada / William Notman's Studio: The Canadian Picture (Montreal: McCord Museum of Canadian History, 1992).

2 Interview with Nora Hague, Photographic Archivist, Notman Photographic Archives, McCord Museum of Canadian History, April 9, 2008.

3 Interview with Cynthia Cooper, Curator of Costume and Textiles, McCord Museum, April 8, 2008.

4 Martha Langford, Telling Pictures and Showing Stories: Photographic Albums in the Collection of the McCord Museum of Canadian History (Montreal: McCord Museum of Canadian History), http://www.mccord-museum.qc.ca/en/.

5 The images are available online, Musée McCord Museum, http://www.mccordmuseum.qc.ca.

6 Anne Higonnet, Pictures of Innocence: The History and Crisis of Ideal Childhood (London: Thames and Hudson, 1998).

7 John R. Gillis, "The Birth of the Virtual Child: A Victorian Progeny," in Beyond the Century of the Child: Cultural History and Developmental Psychology, eds. Willem Koops and Michael Zuckerman (Philadelphia: University of Pennsylvania Press, 2003), 83-95.

8 Martha Langford, Suspended Conversations: The Afterlife of Memory in Photographic Albums (Montreal: McGill-Queen's University Press, 2001).

9 Neil Sutherland, with a new foreword by Cynthia Comacchio, Children in EnglishCanadian Society: Framing the Twentieth-Century Consensus (Waterloo: Wilfrid Laurier University Press, 2000).

10 Jan H. Hunter, How Young Ladies Became Girls: The Victorian Origins of American Girlhood (New Haven: Yale University Press, 2002); Sally Mitchell, The New Girl: Girl's Culture in England 1880-1915 (New York: Columbia University Press, 1995); Lynne Vallone, Disciplines of Virtue: Girls' Culture in the Eighteenth and Nineteenth Centuries (New Haven: Yale University Press, 1995).

11 Julia Thomas, Pictorial Victorians: The Inscription of Values in Word and Image (Athens: Ohio University Press, 2004).

12 Historical publications include: Xiaobei Chen, Tending the Gardens of Citizenship: Child Saving in Toronto 1880s-1920s (Toronto: University of Toronto Press, 2005); Nancy Janovicek and Joy Parr, Histories of Canadian Children and Youth (Don Mills: Oxford University Press, 2003); Françoise Noël, Family Life and Sociability in Upper and Lower Canada, 1780-1870 (Montreal: McGill-Queen's University Press, 2003); Cynthia R. Comacchio, The Infinite Bonds of a Family: Domesticity in Canada, 1850-1940 (Toronto: University of Toronto Press, 1999).

13 Recent exhibitions are: Growing Up in Montréal (McCord Museum, 2004-2007); Picturing Her: Images of Girlhood (McCord Museum, 2005-6): Childhood Revisited, (Markham, ON: Varley Art Gallery, 2005); Nobody's Child: Canada's Home Children (London, ON: London Museum, 2005).

14 John Ruskin, "Sesame and Lilies, Lecture II —Lilies: Of Queens' Gardens," 1865, in Essays: English and American, ed. Charles W. Eliot, The Harvard Classics, 28 (New York: P.F. Collier \& Son, 1909-1917), www.bartleby.com.

15 John Ruskin, Sesame and Lilies (London: Smith, Elder \& Co., 1865). For more information on Ruskin's lectures, see Sara A. Atwood, "John Ruskin on Education," published in the encyclopaedia of informal education, 2008, found at http://www.infed.org/thinkers/john_ruskin.htm.

16 W.J. Lhamon, "John Ruskin as a Political Economist," Canadian Magazine 8, no. 1 (November 1896): 49.

17 "Ruskin's Childhood," The Globe, Monday, December 7, 1885: 03-News. 
18 "Love and Courtship," The Globe, Friday, July 6, 1883: 02-News.

19 “John Ruskin," Northern Messenger 21, no. 13 (June 18, 1886): 2.

20 This undertaking would have been impossible, without Early Canadiana Online, a growing digital library that provides access to over two million pages of Canada's printed heritage, spanning the arrival of the first European settlers to the early twentieth century. See http://www.canadiana.org/eco.

21 Ruskin, Of Queens' Gardens, 78.

22 Ibid., 72.

23 Ibid., 70.

24 Ibid.

25 Author Unknown, "Gardening," Canadian Son of Temperance and Literary Gem. 1, no. 5 (April 22, 1851): 69.

26 Maud C. Cooke, Social Etiquette, or Manners and Customs of Polite Society Containing Rules of Etiquette for All Occasions (London, Ontario: McDermid and Logan, 1896), 395.

27 Ruskin, OfQueens' Gardens, 70.

28 Pye Henry Chavasse, Advice to a Mother on the Management of her Children and on the Treatment on the Moment of Some of Their More Pressing Illnesses and Accidents (Toronto: Willing and Williamson, 1880), 272.

29 Reginald Gourlay, “The Canadian Girl,” Canadian Magazine, 7, no. 4 (August 1896): 506-10.

30 Ibid., 506.

31 Ibid., 508.

32 Janet Badia and Jennifer Phegley, eds. Reading Women: Literary Figures and Cultural Icons from the Victorian Age to the Present (Toronto: University of Toronto Press, 2005); Kate Flint, The Woman Reader 1837-1914 (London: Oxford Clarendon Press, 1993).

33 Ruskin, Of Queens' Gardens, 72.

34 Ibid., 51.

35 Ibid.

36 Ibid, 74.

37 Ibid.

38 Ibid., 78.

39 Madge Merton, "Our Children and their Reading: Part II-A Girl's Reading," Canadian Magazine 9, no. 1 (January 1896): 285-87.

40 For example, Rebecca Agatha Armour, Marguerite Verne, or Scenes from Canadian Life (Saint John, NB: s.n., 1886); Mrs. Baillie Reynolds, The Tree of Knowledge: A Novel (Montreal: J. Lovell, 1889); Adeline Sergeant, Brooke's Daughter: A Novel (Montreal: J. Lovell, 1891).

41 Ruskin, Of Queens' Gardens, 86.

42 Ibid., 68.

43 Author Unknown, "What to Teach our Daughters," Canadian Illustrated News, December 12, 1874: 375.

44 Author Unknown, "The Best Education," Canadian Illustrated News, December 12, 1874: 375 .

45 Author Unknown, "What to Do with the Girls," Canadian Illustrated News, June 3, 1876: 363.

46 Author Unknown, "Hearth and Home-Female Education," Canadian Illustrated News, May 19, 1877: 307.

47 Ruskin, OfQueens' Gardens, 72

48 Merton, "Our Children and their Reading," 286.

49 Notman published illustrated books such as Fennings Taylor and William Notman, Portraits of British Americans by W. Notman with Biographical Sketches by Fennings 
Taylor (Montreal: W. Notman, 1865-68) and contributed to the magazine, Canadian Illustrated News (Montreal: George Desbarats, 1869-1883). See Canadian Illustrated News: Images in the News, http://collectionscanada.gc.ca.

50 Joyce Irene Whalley and Tessa Rose Chester, A History of Children's Book Illustration (London: John Murray with the Victoria \& Albert Museum, 1988).

51 John Ruskin, The Elements of Drawings in Three Letters to Beginners (New York: Maynard, Merrill, 1972; Reprint of the 1893 edition); Robert Hewison, Ruskin and Oxford: The Art of Education (Oxford: Clarendon, 1996).

52 Ruskin, Of Queens' Gardens, 79.

53 Ruskin, The Elements of Drawings, 351-53.

54 Ruskin, OfQueens' Gardens, 79.

55 Hops Ledyard, "Kate’s Choice," Northern Messenger 22 (October 21, 1887): 3.

56 Ruskin, OfQueens' Gardens, 54.

57 Ibid., 74.

58 Ibid.

59 Annie Swan, Courtship and Marriage and the Gentle Art of Home-Making (Toronto: W. Briggs, 1893), 12.

60 The Ladies Book of Useful Information Compiled from Many Sources (London, ON: s.n., 1896), 76.

61 John Ruskin, The Works of John Ruskin (Library Edition), eds. E.T. Cook and Alexander Wedderburn (London: George Allen, 1903-1912), 27:14, quoted in Atwood, "John Ruskin on Education."

62 Christian at Work, "Earning Your Own Living," The Canadian Presbyterian new series 3 no. 31 (June 4, 1880): 491.

63 Gourlay, "The Canadian Girl," 507.

64 Louisa M. Alcott, "The Education of Girls," The Canadian Independent 4, no. 1 (January 1885): 28.

65 Sergeant, Brooke's Daughter, 63.

66 Frances E. Willard, Glimpses of Fifty Years: The Autobiography of an American Woman (Toronto: Woman's Temperance Pub. Association), 54.

67 Author Unknown, "Higher Education for Women," Canadian Illustrated News, August 2, 1873: 78 .

68 Author Unknown, "The Higher Education of Women," Canadian Illustrated News, June 9, 1883: 355.

69 Neil Sutherland, with a new foreword by Cynthia Comacchio, Children in EnglishCanadian Society: Framing the Twentieth-Century Consensus (Waterloo: Wilfrid Laurier University Press, 2000).

70 Cynthia R. Comacchio, The Infinite Bonds of a Family: Domesticity in Canada, 1850-1940 (Toronto: University of Toronto Press, 1999). 